\title{
MS16-P05 | ENVIRONMENTAL EFFECT ON TITANIUM ALLOY TI6242S IN AIR BETWEEN 500 AND $700{ }^{\circ} \mathrm{C}$
}

Kalienko, Maksim (Ural Federal University, Ekaterinburg, RUS)

After a long period at high temperature $\left(>500^{\circ} \mathrm{C}\right)$ titanium alloys present some embrittlement in the form of absence of surface thermal stability. The environmental behavior of Ti6242S alloy was studied in air between 500 and $700{ }^{\circ} \mathrm{C}$ by optical microscopy, scanning electron microscopy, microhardness measurements and $\mathrm{X}$-ray diffraction. The X-ray diffraction analysis was used to study the effect of the oxygen solid solution on the lattice parameters of Ti6242S alloy near the oxide/metal interface. It was found that unit cell lattice parameters of oxygen enriched layer depend on exposure time and temperature. These results indicate that the oxidation mechanism depends on the oxide scale structure and oxygen diffusion process. 